\title{
SPATIAL TEMPORAL STUDY OF SCORPION ENVENOMATION IN THE STATE OF SERGIPE, BRAZIL
}

\section{ESTUDO ESPACIAL E TEMPORAL DOS ENVENENAMENTOS POR ESCORPIÕES NO ESTADO DE SERGIPE, BRASIL}

\author{
Carlos Adriano de Oliveira ALMEIDA ${ }^{1}$; Guilherme Mota da SILVA ${ }^{2}$; Geza Thais Rangel e \\ SOUZA $^{3}$; Rubens Riscala MADI ${ }^{4}$; Andressa Sales COELHO $^{5}$; Cláudia Moura de MELO $^{6}$ \\ 1. Mestre em Saúde e Ambiente, Universidade Tiradentes, Programa de Pós-graduação em Saúde e Ambiente, Aracaju, SE, Brasil. \\ adriano.aracaju@gmail.com; 2. Enfermeiro, Universidade Tiradentes, Curso de Enfermagem, Aracaju, SE, Brasil; 3. Doutora em \\ Ciências Ambientais, Universidade Tiradentes, Programa de Pós-graduação em Saúde e Ambiente, Aracaju, SE, Brasil; 4. Doutor em \\ Parasitologia, Universidade Tiradentes, Programa de Pós-graduação em Saúde e Ambiente, Aracaju, SE, Brasil; 5. Doutora em Ecologia \\ e Recursos Naturais, Universidade Tiradentes, Programa de Pós-graduação em Saúde e Ambiente, Aracaju, SE, Brasil; 6. Doutora em \\ Parasitologia, Universidade Tiradentes, Programa de Pós-graduação em Saúde e Ambiente, Aracaju, SE, Brasil.
}

\begin{abstract}
This is a descriptive, retrospective study using a quantitative approach based on secondary data from records related to scorpion envenomation from the Notifiable Diseases Information System (SINAN - Sistema de Informação de Agravos de Notificação) from 2004 to 2014. The goal was to determine the frequency of scorpion envenomation in the eight territories of the state of Sergipe and to examine spatial differences and environmental influences on envenomation. The study was conducted in the state of Sergipe, Brazil and analysed the relationship between locations most affected by scorpion stings and anthropogenic changes. The following variables were analysed: month and year of the envenomation, territory, area of the envenomation and population according to Brazilian Institute of Geography and Statistics (IBGE - Instituto Brasileiro de Geografia e Estatística). Territorial changes were observed in the neighbourhood of Santos Dumont, in the municipality of Aracaju, that were caused by human occupation in the years 2003, 2009 and 2014. To analyse the climatic influences on the frequency of scorpion stings, we used the normal temperature and normal rainfall in the municipalities of Sergipe, especially in Canindé de São Francisco, Nossa Senhora das Dores and Aracaju, provided by the National Institute of Meteorology and Technology (INMET - Instituto Nacional de Meteorologia e Tecnologia). A total of 8021 accidents with poisonous animals occurred in Sergipe between 2004 and 2014, of which 5133 (63.99\%) involved scorpions; 80\% of scorpion envenomation in Sergipe occurred in urban areas, with significant differences in the distribution per zone between the territories $(\mathrm{P}<0.01)$. The territory of Grande Aracaju (87.9\%) had the highest frequency on scorpion envenomation in urban areas, Alto Sertão (55.9\%) had the highest frequency in rural areas, and the municipality of Aracaju had $58.11 \%$ of all cases of scorpion stings in Sergipe. The neighbourhood of Santos Dumont was the most affected in the municipality of Aracaju, with 219/2983 cases. Regarding preventive measures aimed at the population, it is recommended that individuals maintain cleanliness in the vicinity of their households, avoid accumulating construction waste, use wall coatings, use protective screens in drains and sewers, and seal septic tanks; individuals may also preserve the scorpions' predators.
\end{abstract}

KEYWORDS: Scorpion stings. Time serie. Envenomation

\section{INTRODUCTION}

Scorpion stings are an important public health problem in tropical and subtropical countries.

In Brazil, the prevalence of cases is concentrated in the southeast, though there has been a significant increase in cases from the northeastern states, particularly Bahia, Rio Grande do Norte, Pernambuco, Alagoas and Ceará (BARROS et al., 2014 ).

In Sergipe, scorpion stings have increased in the last decade. This may be related to the modification of territories as described by Mesquita et al. (2015), who suggest that urban sprawl increases the accumulation of debris and garbage near houses, thus increasing the risks of scorpion proliferation.
Accidents in rural areas are assumed to be related to the destruction of natural areas for the exploitation of agribusiness. Wagatsuma et al. (2003) noted that intensive deforestation, with the substitution of planted areas, has devastated the regions of native forests and caused changes in local, regional and global environmental and climatic factors, such as temperature, soil moisture, and air.

The assessment of scorpion envenomation in the state of Sergipe can support decision-making to create interdisciplinary educational activities, both for the general population and for professionals from different areas, that consider territorial aspects.

The objective of this study was to determine the frequency of scorpion envenomation in the eight territories of the state of Sergipe according to 
demographic and climatic variables and to examine spatial differences in the events and processes that influence the accidents.

\section{MATERIAL AND METHODS}

\section{Type of study}

This was a descriptive, retrospective study using a quantitative approach based on secondary data drawn from reports of envenomation involving venomous scorpions in the Notifiable Diseases Information System (SINAN - Sistema de Informação de Agravos de Notificação) from 2004 to 2014 .

Study area

The study was conducted in the state of Sergipe, located in northeastern Brazil, which occupies an area of $21915.116 \mathrm{Km}^{2}$ and had an estimated population of 2219574 inhabitants in 2014. The population is distributed in eight territories that form the basis for the planning of public policies, and these consist of Alto Sertão, Médio Sertão, Baixo São Francisco, Agreste Central, Leste, Grande Aracaju, Centro Sul and Sul (SERGIPE, 2007).

\section{Data collection}

Secondary data were collected from records of scorpion envenomation in the SINAN from 2004 to 2014 that were obtained from the State Department of Health of Sergipe.
The data were stratified according to the territories of Sergipe. The following variables were analysed: year and month of the accident and territory and area of the envenomation (urban, rural and peri-urban). We calculated the absolute and relative frequencies of scorpion stings for the territory.

To analyse the relationship between locations most affected by scorpion envenomation in the state of Sergipe and anthropogenic modifications, the neighbourhood of Santos Dumont $\left(10^{\circ} 89^{\prime} \mathrm{S}\right.$ and $\left.37^{\circ} 09^{\prime} \mathrm{W}\right)$, which is located in the municipality of Aracaju $\left(10^{\circ} 54^{\prime} \mathrm{S}\right.$ and $\left.37^{\circ} 04^{\prime} \mathrm{W}\right)$ in the territory of Greater Aracaju, was used as an example. This neighbourhood was chosen because it has the highest frequency of scorpion envenomation in the most affected municipality of Sergipe and because the availability of maps over time allow adequate visual definition to characterize territorial changes over the period of 2004 to 2014.

The profiles of poisonous animal envenomation vary between territories and between urban and rural areas, and scorpion stings are uncommon in rural areas. Therefore, we initially tried to scale the human population at risk of poisonous animal envenomation, especially for scorpion stings in each area and territory of Sergipe, using population data from 2010 (Table 1) and a survey of the dynamics of these populations.

Table 1. Distribution of the population by sex, region and territory in Sergipe in 2010 according to IBGE census (IBGE, 2016).

\begin{tabular}{lccccccc}
\hline \multirow{2}{*}{ TERRITORY } & \multicolumn{3}{c}{ Resident Population } & \multicolumn{2}{c}{ Men } & \multicolumn{2}{c}{ Women } \\
\cline { 2 - 9 } & General & $\begin{array}{c}\text { Urban } \\
\text { Area }\end{array}$ & $\begin{array}{c}\text { Rural } \\
\text { Area }\end{array}$ & $\begin{array}{c}\text { Urban } \\
\text { Area }\end{array}$ & $\begin{array}{c}\text { Rural } \\
\text { Area }\end{array}$ & $\begin{array}{c}\text { Urban } \\
\text { Area }\end{array}$ & $\begin{array}{c}\text { Rural } \\
\text { Area }\end{array}$ \\
\hline ALTO SERTÃO & 146479 & 68339 & 78140 & 33311 & 40570 & 35028 & 37570 \\
MÉDIO SERTÃO & 64390 & 38797 & 25593 & 18683 & 13149 & 20114 & 12444 \\
AGRESTE CENTRAL & 232495 & 143692 & 88803 & 69347 & 45437 & 74345 & 43366 \\
BAIXO SÃO FRANCISCO & 125174 & 72655 & 52519 & 35572 & 26915 & 37083 & 25604 \\
LESTE & 97726 & 59036 & 38690 & 28631 & 19838 & 30405 & 18852 \\
GRANDE ARACAJU & 930245 & 875756 & 54489 & 412924 & 27931 & 462832 & 26558 \\
CENTRO SUL & 222972 & 118705 & 104267 & 56410 & 53028 & 62295 & 51239 \\
SUL & 248536 & 143386 & 105150 & 69038 & 54257 & 74348 & 50893 \\
\hline TOTAL & 2068017 & 1520366 & 547651 & 723916 & 281125 & 796450 & 266526 \\
\hline$\%$ & 100.00 & 73.52 & 26.48 & 35.01 & 13.59 & 38.51 & 12.89 \\
\hline
\end{tabular}

To estimate the population variation, we used population data provided by the IBGE from the 2000 census, the 2007 population counts and the 2010 census of the municipality of Aracaju and the neighbourhood of Santos Dumont in the same municipality.
The territorial changes in the neighbourhood of Santos Dumont in the municipality of Aracaju that were caused by human occupation were found using images provided by the Google Earth tool from 2003, 2009, and 2014, which were accessed in 2016. 
To analyse the climatic influences of the frequency of scorpion stings, the cities of Aracaju in the territory of Grande Aracaju, Canindé do São Francisco $\left(9^{\circ} 40^{\prime} \mathrm{S}\right.$ and $\left.37^{\circ} 47^{\prime} \mathrm{W}\right)$ in the territory of Alto Sertão, and Nossa Senhora das Dores $\left(10^{\circ} 29^{\prime} \mathrm{S}\right.$ and $37^{\circ} 11^{\prime} \mathrm{W}$ ) in the territory of Médio Sertão were used as examples. The available data from 20042014 on the average normal temperature and rainfall provided by the National Institute of Meteorology and Technology (INMET - Instituto Nacional de Meteoriologia e Tecnologia) were used, and climate differences were found using the Köppen (PEEL; FINLAYSON; MCMAHON, 2007). These municipalities were chosen because they represent extremes both the frequency of scorpion stings and climate variations.

Statistical analysis

To perform the statistical calculations, we used SPSS version 21.0 and BioEstat version 5.3. Descriptive analysis and analysis of variance were performed, depending on the prerequisites and suitability, using one-factor ANOVA with the post hoc Sidak or Kruskal-Wallis test. We calculated the Pearson correlation coefficient between the frequency of scorpion stings and changes in temperature and rainfall. All tests were performed with $95 \%$ confidence $(\mathrm{p}<0.05)$.

\section{Ethical aspects}

The study was approved by the Research Ethics Committee of the University Tiradentes, with CAAE 39543814.3.0000.5371 and document number 946982.

\section{RESULTS AND DISCUSSION}

Despite the existence of other information systems that record data on poisonous animal envenomation, including the National System of Toxic-Pharmacological Information (SINITOX Sistema Nacional de Informações TóxicoFarmacológicas), it was decided to use the SINAN because it is more comprehensive and has the ability to collect information from all state health services (BOCHNER, 2013), while the SINITOX collects information only from the Center for Information and Toxicological Assistance (CIATOX - Centro de Informação e Assistência Toxicológica) (MESQUITA et al., 2015).

Between 2004 and 2014, there were 8021 cases of poisonous animal envenomation in Sergipe, most of which involved scorpions; scorpion accidents were more common than snake accidents (Table 2).

Table 2. Distribution of poisonous animal accidents by area between 2004 and 2014 in the state of Sergipe.

\begin{tabular}{lccc}
\hline \multicolumn{1}{c}{ Animal } & Scorpions & Snakes & Other animals \\
\hline All areas & $5133(63.99 \%)$ & $1673(20.85 \%)$ & $1215(15.14 \%)$ \\
Urban area & $4101(51.16 \%)$ & $483(6.02 \%)$ & $739(9.21 \%)$ \\
Rural area & $490(6.10 \%)$ & $1014(12.64 \%)$ & $361(4.50 \%)$ \\
Peri-urban area & $202(2.51 \%)$ & $77(0.95 \%)$ & $46(0.57 \%)$ \\
No information & $337(4.20 \%)$ & $99(1.23 \%)$ & $69(0.86 \%)$ \\
\hline
\end{tabular}

Regarding the frequency of scorpion envenomation in relation to accidents with all poisonous animals, similar results were found in other studies in the northeast of Brazil, where scorpions envenomation in Pernambuco and Rio Grande do Norte States were $60.3 \%$ and $65.4 \%$, respectively (ALBUQUERQUE et al., 2013; BARBOSA, 2014). A study conducted in Sergipe by Mesquita et al. (2015) found a similar situation (64.79\% of cases) using CIATOX data from 2002 to 2012.

The current distribution of the population in urban and rural areas is the result of historical processes in Sergipe where a rural exodus was caused by climatic, economic and political factors in certain regions.
These historical demographic factors can help to explain the relationship between the human population distribution in the territories and the rural and urban location of poisonous animal envenomation, especially those involving scorpions. This can also aid in understanding the preventive, curative and administrative aspects of these accidents.

In Sergipe, scorpion stings have increased in the last decade (Figure 1), and this may be related to the uncontrolled growth of urban areas and the consequent increase in debris accumulation and waste near houses (MESQUITA et al., 2015). In the last 40 years, the urban population has overtaken the rural population of Sergipe; in 1970, 46.24\% of the population of Sergipe lived in cities, and this increased to $73.51 \%$ in the 2010 s (IBGE, 2016). 


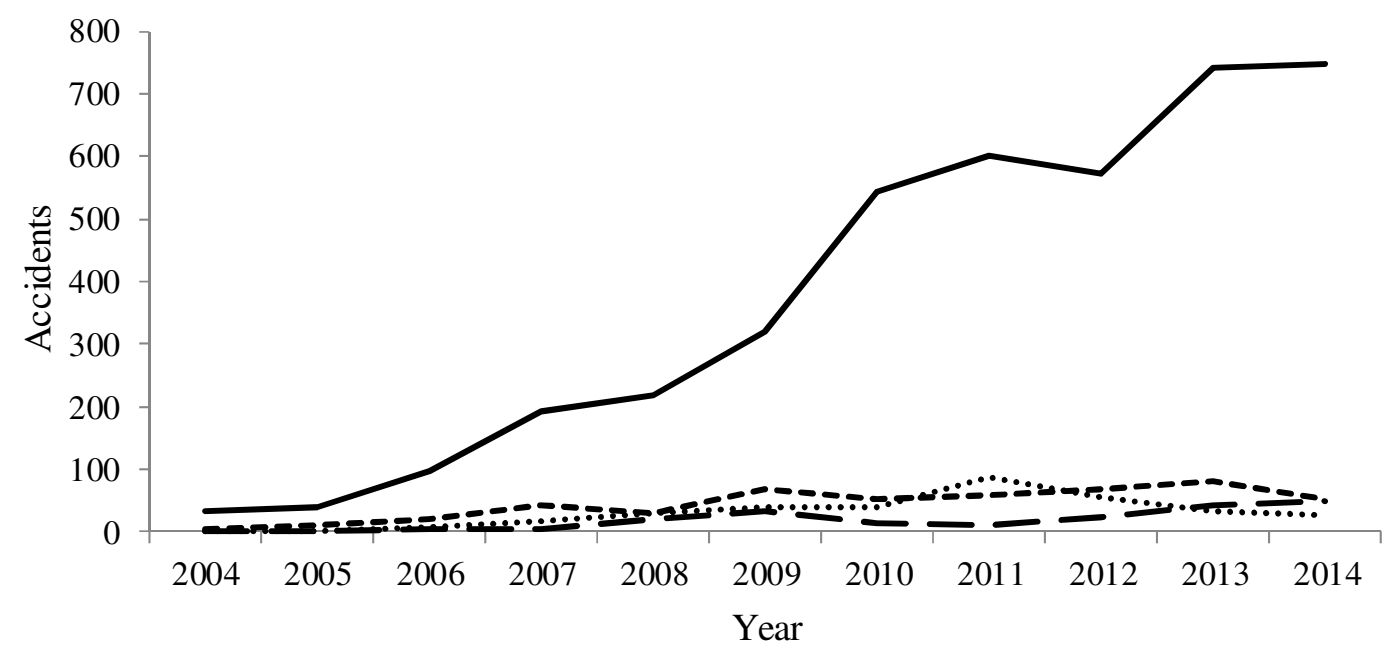

—Urban Area ---- Rural Area — - Peri-urban Area ….... Unknown

Figure 1. Trend in the number of scorpion accidents from 2004 to 2014 in the state of Sergipe.

The results show that from 2004 to 2014 in Sergipe, most scorpion accidents in all territories except Alto Sertão and Centro Sul occurred in urban areas (Table 3). In Brazil, the frequency of scorpion envenomation in urban areas is $61.7 \%$ (RECKZIEGEL; PINTO, 2014). A previous study by Mesquita et al. (2015) using the SINITOX found the frequency of this type of envenomation to be $90.3 \%$ in Sergipe.

The area where scorpion stings occurred differed significantly between regions $(\mathrm{F}=190.835$ and $\mathrm{p}<0.001$, Table 3 ).

Table 3. Distribution by area of occurrence of the Scorpion stings in the State of Sergipe.

\begin{tabular}{|c|c|c|c|c|c|c|c|c|c|c|}
\hline & & & \multirow[b]{2}{*}{$\underset{6}{Ð}$} \\
\hline & & 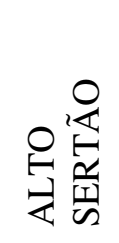 & 商点 & 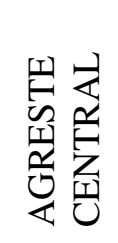 & 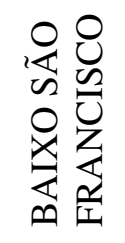 & 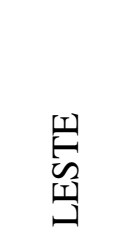 & 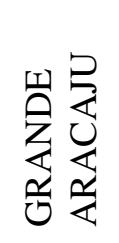 & 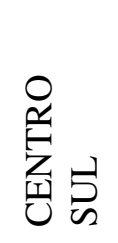 & $\vec{s}$ & \\
\hline \multirow[t]{2}{*}{ URBAN } & $\mathrm{AF}$ & 12 & 16 & 318 & 114 & 53 & 3462 & 47 & 82 & 4104 \\
\hline & $\mathrm{RF}$ & $35.3 \%$ & $50.0 \%$ & $50.9 \%$ & $68.3 \%$ & $68.8 \%$ & $87.9 \%$ & $36.4 \%$ & $62.6 \%$ & $79.9 \%$ \\
\hline \multirow[t]{2}{*}{ RURAL } & $\mathrm{AF}$ & 19 & 13 & 208 & 48 & 20 & 87 & 63 & 32 & 490 \\
\hline & $\mathrm{RF}$ & $55.9 \%$ & $40.6 \%$ & $33.3 \%$ & $28.7 \%$ & $25.9 \%$ & $2.2 \%$ & $48.8 \%$ & $24.4 \%$ & $9.5 \%$ \\
\hline PERI- & $\mathrm{AF}$ & 3 & 0 & 10 & 2 & 3 & 177 & 2 & 5 & 202 \\
\hline URBAN & $\mathrm{RF}$ & $8.8 \%$ & $0.0 \%$ & $1.6 \%$ & $1.2 \%$ & $3.9 \%$ & $4.5 \%$ & $1.6 \%$ & $3.8 \%$ & $3.9 \%$ \\
\hline \multirow[t]{2}{*}{ UNKNOWN } & $\mathrm{AF}$ & 0 & 3 & 88 & 3 & 1 & 213 & 17 & 12 & 337 \\
\hline & $\mathrm{RF}$ & $0.0 \%$ & $9.4 \%$ & $14.1 \%$ & $1.8 \%$ & $1.3 \%$ & $5.4 \%$ & $13.2 \%$ & $9.2 \%$ & $6.6 \%$ \\
\hline TOTAL & & 34 & 32 & 624 & 167 & 77 & 3939 & 129 & 131 & 5133 \\
\hline
\end{tabular}

$\mathrm{AF}$ - absolute frequency; RF - relative frequency

The territories of Grande Aracaju had a higher frequency relative to urban areas. The opposite occurred in the territory of Alto Sertão, which had a higher frequency in countryside and had the highest percentage among peri-urban areas. Differences statistically significant were found between the absolute frequency of scorpion envenomation in various zones within territories $(\mathrm{F}=10.8269$ and $\mathrm{p}<0.001)$. These differences occurred gradually, and their evolution can be seen in timeline distribution of cases in the state (Figure 2). 

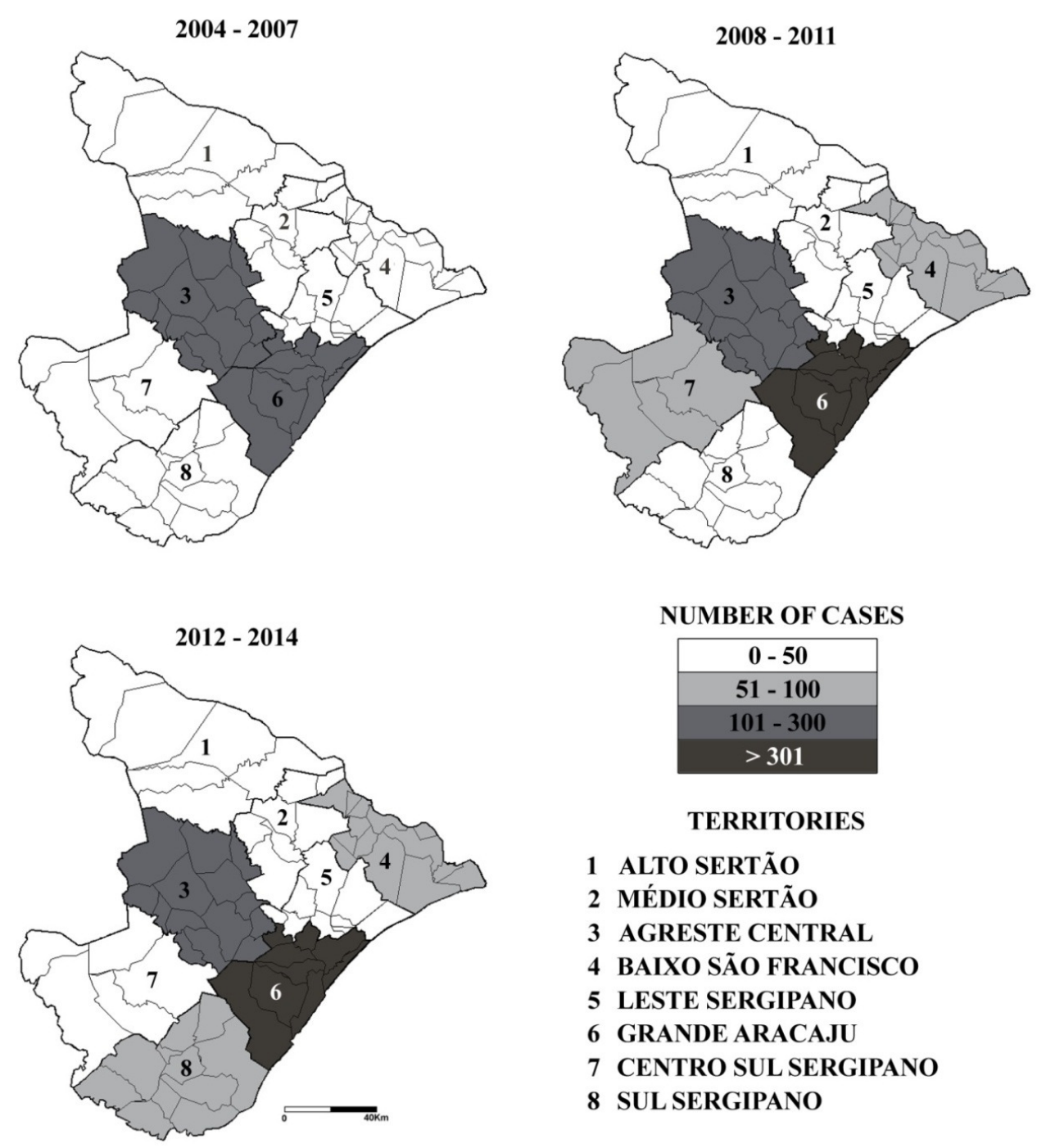

\section{NUMBER OF CASES}

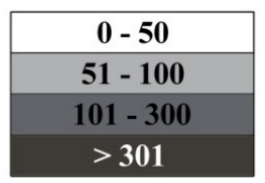

\section{TERRITORIES}

1 ALTO SERTÃo

2 MÉDIO SERTÃO

3 AGRESTE CENTRAL

4 BAIXO SÃO FRANCISCO

5 LESTE SERGIPANO

6 GRANDE ARACAJU

7 CENTRO SUL SERGIPANO

8 SUL SERGIPANO

Figure 2. Evolution of spatial temporal cases of scorpion accidents in Sergipe territories from 2004 to 2014.

The territory of Grande Aracaju had high relative frequencies and maintained high rates over the study period. Between 2004 and 2014, the municipality of Aracaju reported 2983 of the 5133 $(58.11 \%)$ scorpion bites in the state of Sergipe, and the Santos Dumont neighbourhood had the highest number of incidents recorded, $7.60 \%$ of the cases $(219 / 2983)$.
The observation of the dynamics of human population development in areas affected by scorpion envenomation was based on the population database available through the IBGE and was calculated as the rate of population growth in the city of Aracaju and its most affected district (Table 4).

Table 4. Resident population in the municipality of Aracaju and in the neighbourhood of Santos Dumont, Aracaju - Sergipe.

\begin{tabular}{lccc}
\hline & $2000^{*}$ & $2007 * *$ & $2010^{* * *}$ \\
\hline Aracaju & 461534 & 520303 & 571149 \\
Population growth rate (\% per year) & 1.89 & 1.73 & 3.16 \\
Neighbourhood of Santos Dumont & 23593 & 25061 & 25808 \\
Population growth rate (\% per year) & 1.41 & 0.87 & 0.98 \\
\hline
\end{tabular}

* Census 2000; ** Population Count 2007; *** Census 2010 
According to Table 4, the growth rate of the population of Aracaju was higher than that in the Santos Dumont neighbourhood in the analysed period, although the relative population growth was impacted by changes in the physical space of the localities that caused changes in the environment, as seen in Figure 3.
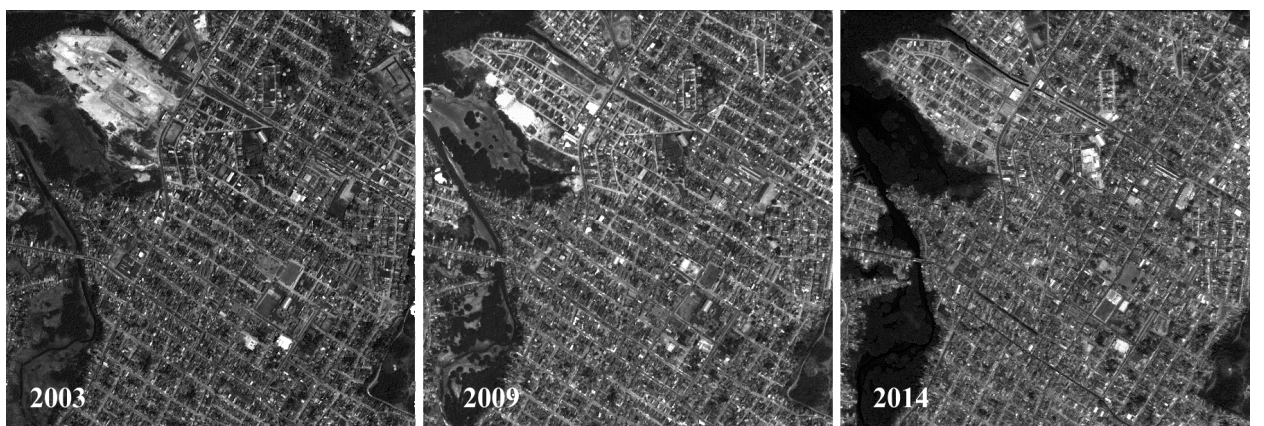

Figure 3. Spatial occupation and environmental changes in the neighbourhood of Santos Dumont, municipality of Aracaju, in 2003, 2009, and 2014. Source: Google Earth, 2016.

When analysing the images, it is clear that the population of the territory altered the natural spaces according to their needs, thereby generating environmental changes. An understanding of historical population movement is important for assessing the impact in the suburbs of the municipality most affected by scorpion stings, and this allows equivalent analysis throughout the territory of Grande Aracaju.

Until the 1970s, agriculture was the main economic activity of Sergipe. Since then, several investments have increased participation in the industrial sector, which has altered the composition of the Gross Domestic Product (GDP/PIB - Produto Interno Bruto). This growth generated socioeconomic and spatial changes with increasing expectations of the provincial population of the State for better living conditions, which intensified migration to the capital of Sergipe and its vicinity. Thus, in 1980, 54.2\% of the population of Sergipe lived in urban areas, mainly in the municipality of Aracaju and its surrounding municipalities, while in 1970, 53.8\% of the population of Sergipe lived in rural areas (FEITOSA, 2014).

According to Nodari; Leite; Nascimento (2006), population growth in urban areas resulted in a housing shortage and economic inability to accommodate this population in the capital, which caused expansion to more peripheral areas. This generated significant environmental changes. The illegal occupation of areas led to poor housing conditions, which caused proliferation of arachnids and a consequent increased risk of envenomation (SPIRANDELI-CRUZ;

YASSUDA;

BARRAVIERA, 1995).

Heavy residues often accumulate on houses and buildings that lack external finishing or coated walls. Poor infrastructure and sanitation facilitate the spread of cockroaches and other insects, which provide rich food sources that encourage scorpion proliferation.

The territory of Grande Aracaju has the largest concentration of the population residing in urban areas. The risks related to scorpion accidents differ from the risks in territories with large rural populations, such as Alto Sertão.

In urban areas, disorganized human occupation interferes with scorpion proliferation. In rural areas, other issues such as agricultural activities, low technology use, advancement of the agricultural frontier that destroys natural areas and climatic factors can influence poisonous animal accidents, including scorpion envenomation.

In some territories, the accident profile in rural areas is related to aspects of agriculture, and precisely to the production of these places. For example, in Centro Sul, most accidents occur in rural areas despite a large urban population. In other territories, such as Agreste Central, family farming has a strong impact on the local economy (ALMEIDA; JESUS; VIEIRA, 2013). In particular, the city of Itabaiana and its surrounding municipalities are large producers of fruits and vegetables.

In many regions of Brazil, family farming is the predominant form of production, and this is essential for local economies (SANTOS, 2001). However, many traditional livestock and agriculture activities occur without proper use of the most developed technologies, including personal protective equipment (LIMA; VASCONCELOS, 2006). This exposes rural workers to a high risk of poisonous animal accidents, including scorpion 
envenomation (BRASIL; ZUMKELLER; BRITESNETO, 2013).

Scorpion stings in rural areas are related to the expansion of agricultural frontiers, especially in the setting of monocultures. This destroys native forests, which are the natural habitat of scorpions and their natural predators, such as monkeys, raccoons, frogs and birds; these small populations facilitate the dispersion of various species of scorpions (COSTA, 2012).

Among the scorpion envenomation that occurred in Sergipe, the territory the Alto Sertão had the highest frequency relative to rural areas $(55.9 \%)$, but in absolute numbers, it had 34 cases over 11 years; the territory of Médio Sertão had 32 cases, and these two areas had the fewest number of scorpion envenomation in the state.

Seeking possible reasons for the differences in absolute frequencies in these territories, we compared temperature and rainfall between the cities of Aracaju (Grande Aracaju), Canindé do São Francisco (Alto Sertão), and Nossa Senhora das Dores (Médio Sertão).

The municipality of Aracaju has a temperature between $26.9^{\circ} \mathrm{C}$ and $30.8^{\circ} \mathrm{C}$ (mean of $29.01 \pm 1.34^{\circ} \mathrm{C}$ ) and periods of regular rainfall throughout the year that intensify between April and August (between $103.91 \mathrm{~mm}$ and $240.80 \mathrm{~mm}$ ); the annual volume is $1136 \mathrm{~mm}$ (mean of $94.74 \pm 66.36$ $\mathrm{mm}$ ). It is noteworthy that the absolute frequency of scorpion envenomation in Aracaju remained relatively constant, ranging from 213 to 272 cases over 12 months (mean of $248.58 \pm 19.44$ cases). According to the classification of Köppen, Aracaju is defined as tropical rainy (As), where the lowest average temperature of the year is always higher than $18^{\circ} \mathrm{C}$ and where strong annual rainfall is in excess of evapotranspiration. The correlations between scorpion stings and changes in temperature and rainfall in the city of Aracaju, although positive, were not significant $(r=0.3579 ; p=0.2533$ and $r=$ $0.0385 ; \mathrm{p}=0.9054$, respectively).

The municipality of Canindé do São Francisco has the highest average temperature in the three municipalities evaluated, ranging from $28.04^{\circ} \mathrm{C}$ to $33.26^{\circ} \mathrm{C}$ (mean of $31.01 \pm 1.89^{\circ} \mathrm{C}$ ). The Köppen classifies the region as arid steppes (BSh), where average annual temperature is greater than $18^{\circ} \mathrm{C}$, where desert areas or semi-deserts are present, and where evapotranspiration exceeds precipitation; it has the lowest rate of rainfall, ranging between $12.20 \mathrm{~mm}$ and $80.60 \mathrm{~mm}$, and its total volume of annual precipitation does not exceed $600 \mathrm{~mm}$ (mean of $47.98 \pm 23.03 \mathrm{~mm}$ ). The absolute frequency of scorpion envenomation in Canindé do
São Francisco ranged from 0 to 4 cases over 12 months (mean of $2.17 \pm 1.53$ cases). Temperature correlated negatively with scorpion envenomation ( $\mathrm{r}$ $=-0.4195 ; \mathrm{p}=0.1747)$, while the precipitation showed the opposite behaviour $(\mathrm{r}=0.3114 ; \mathrm{p}=$ 0.3246).

The city of Nossa Senhora das Dores had a greater temperature change than Aracaju but similar rainfall, while the rainfall was relatively higher and the temperature index was lower (mean of $30.08 \pm 1.94^{\circ} \mathrm{C}$ ) than in Canindé do São Francisco. The Köppen classifies the region as tropical, with winter and autumn rainfall (As'), temperatures above $18^{\circ} \mathrm{C}$, and rainfall exceeding evapotranspiration. Its rainy season, between April and August, produces monthly rainfall between $118.41 \mathrm{~mm}$ and $183.64 \mathrm{~mm}$, with annual volumes of $1117 \mathrm{~mm}$ (mean of $93.15 \pm 57.61 \mathrm{~mm}$ ). The absolute frequency of scorpion stings in Nossa Senhora das Dores ranged from 0 to 5 cases over 12 months (mean of $2.00 \pm 1.76$ cases). As in Canindé do São Francisco, the correlation between scorpion envenomation and temperature was negative $(\mathrm{r}=$ $0.2058 ; \mathrm{p}=0.5209)$, while the correlation with rainfall was positive $(\mathrm{r}=0.1763 ; \mathrm{p}=0.5836)$.

The negative correlation between the frequency of the scorpion stings and the temperature of territories located in the Sergipe hinterland shows that envenomation may be less likely during hot times of the day or year. The seasonality of scorpion envenomation in the northeast is directly linked to reproductive and dietary aspects (OLIVEIRA; WEN; SIFUENTES, 2009), although Araújo et al. (2010) state that there is a relationship between rainfall and the presence of scorpions on the soil surface, which facilitates their encounter with humans.

Pinto-da-Rocha et al. (2007) found an association between the dry season and scorpion reproduction, with the rainy season corresponding to the embryonic period. Scorpions are most active in wet locations (BRASIL, 2009), and in dry conditions they only come out of hiding when it is necessary to seek food or for reproduction, being more frequent, in these situations, at night (VACHON, 1952).

The lower frequencies of scorpion envenomation in the municipality of Canindé do São Francisco may be related to low rainfall index, high temperature or the presence or absence of species that are hazardous to humans. While these accidents may not represent a significant number of all the cases in Sergipe from 2004 to 2014, 76.5\% (26/34) of the cases occurred in the territory the 
Alto Sertão, highlighting the relative importance of this municipality within the territory.

Canindé do São Francisco had the most cases of any municipality in its territory, and it should be noted that it borders the state of Alagoas, which has one of the highest incidence of scorpion envenomation in Brazil (BRASIL, 2009). Of course, we are unable to list all relevant events in this city and in the neighbouring state.

It appears that other elements may cause the differences in the frequency of scorpion stings, as the weather conditions are similar in the cities of Nossa Senhora das Dores and Aracaju. The difference may be due to the size of the cities' urban populations, the adaptability and living conditions of scorpion species living in each place, the level of natural environment preservation, the presence of prey and predators, and the reproductive capacity of the scorpions.

The expansion of the human population allows increases among harmful species of scorpions, as with the destruction of natural environments creates space for opportunistic and adaptable species that occupy the empty niches left by the reduction or disappearance of species that previously lived there in equilibrium. These opportunistic species, given these conditions created by urbanization, tend to reproduce more quickly and increase their population, which heightens the risk of scorpion stings (LOURENÇO et al., 1996).

Behaviour of the scorpion species in Sergipe is unknown, and there are no specific publications related the scorpion ecology in the state. This study found an increase in absolute frequencies of scorpion envenomation in Sergipe between 2004 and 2014; we investigated the relationship between population density and concentration of scorpion stings and found that increasing human populations were related to the destruction of the scorpions' habitat. Unfinished walls within homes and the accumulation of building waste near residences were common in areas with a high frequency of scorpion envenomation. Additionally, rainfall was positively associated with scorpion stings, while high temperatures in warmer regions of the state are related to fewer scorpion envenomation.

Field studies are needed to identify and locate the species of scorpions, as there is a lack of knowledge about the distribution of these animals in Sergipe.

Education of the population and professionals from various sectors, especially the health sector, on the impact on health promotion and prevention of poisonous animal accidents is important for better protection of people and the environment.

Preventive measures aimed at the population, such as maintaining cleanliness around households, removing construction waste/debris, lining walls, avoiding cavities that could serve as hiding places for scorpions and other animals and using protective screens in drain sewers and maintaining sealed septic tanks, in addition to the proper use of personal protective equipment by farm workers, should be adopted.

It is also important to preserve the natural predators of scorpions, especially owls, lizards, frogs and others, and to recognize that scorpions only attack people when they are defensive, which puts the burden on people to prevent encounters.

RESUMO: Estudo descritivo, retrospectivo de abordagem quantitativa com base em dados secundários, extraídos das notificações de envenenamentos por escorpião no Sistema de Informação de Agravos de Notificação (SINAN) no período de 2004 a 2014. O objetivo foi determinar a frequência de envenenamentos por escorpiões nos oito territórios sergipanos, verificando as diferenças espaciais nas ocorrências e as influências ambientais sobre os envenenamentos. O estudo foi realizado no Estado de Sergipe, Brasil, e analisou a relação entre localidades mais acometidas por acidentes escorpiônicos e modificações antrópicas. As variáveis analisadas foram: ano e mês do envenenamento, território, zona de ocorrência e população segundo Instituto Brasileiro de Geografia e Estatística (IBGE). Verificaram-se as modificações territoriais no bairro Santos Dumont, no município de Aracaju, causadas pela ocupação humana nos anos de 2003, 2009 e 2014. Para analisar as influências climáticas nas frequências de envenenamentos por escorpiões, utilizou-se as normais de temperatura e normais de pluviosidade dos municípios de Sergipe, em especial Canindé do São Francisco, Nossa Senhora das Dores e Aracaju, fornecidos pelo Instituto Nacional de Meteorologia e Tecnologia (INMET). Verificou-se a ocorrência de 8021 casos de acidentes com animais peçonhentos em Sergipe no período entre 2004 e 2014, dos quais 5133 (63,99\%) envolveram escorpiões; 80\% dos casos de acidentes escorpiônicos em Sergipe, ocorreram em zona urbana, com diferenças estatísticas na distribuição por zona entre os territórios ( $\mathrm{p}<0,01$ ). $\mathrm{O}$ território da Grande Aracaju (87,9\%) apresentou a maior frequência de envenenamentos em zona urbana; o Alto Sertão $(55,9 \%)$ obteve a maior frequência em zona rural; o município de Aracaju concentrou 58,11\% de todos os casos de acidentes escorpiônicos de Sergipe. O bairro Santos Dumont foi o mais acometido do município de Aracaju com $219 / 2983$ casos. Em relação às medidas preventivas voltadas à população é recomendável orientar sobre a manutenção da limpeza no entorno dos domicílios; evitar resíduos de construção civil; realizar o acabamento das paredes através de revestimentos; 
utilizar telas protetoras nos ralos de esgotos e manter fossas sépticas lacradas, além de preservar os predadores dos escorpiões.

PALAVRAS - CHAVE: Picadas de escorpião. Série temporal. Acidente.

\section{REFERENCES}

ALBUQUERQUE, C. M. R.; NETO, P. L. S.; AMORIM, M. L. P.; PIRES, S. C. V.; Pediatric epidemiogical aspects of scorpionism and report on fatal cases from Tityus stigmurus stings (Scorpiones: Buthidae) in State of Pernambuco, Brazil. Rev. Soc. Bras. Med. Trop., v. 46, n. 4, p. 484-489, 2013.

http://dx.doi.org/10.1590/0037-8682-0089-2013

ALMEIDA, D. C.; JESUS, E. S.; VIEIRA, S. A. Agricultura familiar em Sergipe. Rev. Eletrôn. Fac. José Augusto Vieira, v. 6, n. 2, p. 89-100, 2013.

http://www.fjav.com.br/revista/Downloads/EdicaoEspecialdaPosLatoSensuemTerritorioDesenvolvimentoMeio Ambiente2013/Artigo89_100.pdf

ARAÚJO, C. S.; CANDIDO, D. M.; ARAÚJO, H. F. P.; DIAS, S. C.; VASCONCELLOS, A. Seasonal variations in scorpion activities (Arachnida: Scorpiones) in an area of Caatinga vegetation in northeastern Brazil. Zoologia, v. 27, n. 3, p. 372-376, 2010. http://dx.doi.org/10.1590/S1984-46702010000300008

BARBOSA, I. R. Aspectos do escorpionismo no Estado do Rio Grande do Norte. Rev. Saúde Com., v. 10, n. 1, p. 43-53, 2014. http://www.uesb.br/revista/rsc/v10/v10n1a04.pdf

BARROS, R. M.; PASQUINO, J. A.; PEIXOTO, L. R.; TARGINO, I. T. G.; SOUSA, J. A.; LEITE, R. S. Clinical and epidemiological aspects of scorpion stings in the northeast region of Brazil. Ciênc. saúde colet., v. 19, n. 4, p. 1275-1282, 2014. http://dx.doi.org/10.1590/1413-81232014194.01602013

BOCHNER, R. Informação sobre intoxicações e envenenamento para a gestão do SUS: um panorama do Sistema Nacional de Informações Tóxico-Farmacológicas - SINITOX. RECIIS - Rev. Eletrôn. de Comum. Inf. Inov. Saúde, v. 7, n. 2, 2013. http://dx.doi.org/10.3395/reciis.v7i2.472

BRASIL, J.; ZUMKELLER, S.; BRITES-NETO, J. Perfil histórico do escorpionismo em americana, São Paulo, Brasil. Hygeia, v. 9, n. 17, p. 158-167, 2013.

http://www.seer.ufu.br/index.php/hygeia/article/view/23044

BRASIL, Ministério da Saúde. Manual de controle de escorpiões. Série B. Textos Básicos de Saúde. Brasília (DF). Ministério da Saúde [manual online]. 2009.

http://bvsms.saude.gov.br/bvs/publicacoes/manual_controle_escorpioes.pdf

COSTA, L. S. O. C. Aspectos epidemiológicos do escorpionismo na região de Santarém, Estado do Pará, Brasil. Rev. Colombiana cienc. Anim., v. 4, n. 1, p. 59-68, 2012. https://dialnet.unirioja.es/ejemplar/307260

FEITOSA, C. O. A distribuição espacial das atividades econômicas de Sergipe. Cad. Ciênc. Soc. Aplic., v. 11, n. 17, p. 187-206, 2014. http://periodicos.uesb.br/index.php/cadernosdeciencias/article/viewFile/4924/4719

INSTITUTO BRASILEIRO DE GEOGRAFIA E ESTATÍSTICA [IBGE], Estados@. Access on February 1, 2016. Available in: http://ibge.gov.br/estadosat/perfil.php?sigla=se

LIMA, K. E. C.; VASCONCELOS, S. D. Acidentes com animais peçonhentos: um estudo etnozoológico com agricultores de Tacaratu, sertão de Pernambuco. Sitientibus série Ciênc. Biol., v. 6, n. 2, p. 138-144, 2006. http://www2.uefs.br/revistabiologia/pg6_n2.html 
LOURENÇO, W. R.; CLOUDSLEY-THOMPSON J. L.; CUELLAR, O.; VON EICKSTEDT, V. R. D.; BARRAVIERA, B.; KNOX, M. B. The evolution of scorpionism in Brazil in recent years. J. Venom. Anim. Toxins inc. Trop. Dis., v. 2 n. 2, p. 121-134, 1996. http://dx.doi.org/10.1590/S0104-79301996000200005

MESQUITA, F., NUNES, M., SANTANA, V., MACHADO NETO, J., ALMEIDA, K., LIMA, S. Acidentes escorpiônicos no Estado de Sergipe - Brasil. Rev. Fac. Ciênc. Méd. Sorocaba, v. 17, n. 1, p. 15-20, 2015. http://revistas.pucsp.br/index.php/RFCMS/article/view/19842/pdf

NODARI, F. R.; LEITE, M. L.; NASCIMENTO, E. Aspectos demográficos, espaciais e temporais dos acidentes escorpiônicos ocorridos na área de abrangência da $3^{\mathrm{a}}$ Regional de Saúde - Ponta Grossa, PR, no período de 2001 a 2004. Publ. UEPG Ci. Biol. Saúde, v. 12, n. 1, p.15-26, 2006.

http://dx.doi.org/10.5212/publicatio\%20uepg.v12i1.425

OLIVEIRA, R. C.; WEN, F. H.; SIFUENTES, D. N. Epidemiologia dos acidentes por animais peçonhentos. In: CARDOSO, J. L. C.; FRANÇA, F. O. S.; FAN, H.W. (Ed.) Animais peçonhentos no Brasil: biologia clínica e terapêutica dos acidentes. São Paulo: Salvier, 2009. p. 06-21.

PEEL, M. C.; FINLAYSON, B. L.; MCMAHON, T. A. Updated world map of the Köppen-Geiger climate classification. Hydrol. Earth Syst. Sci. Discuss., v. 11, n. 5, p. 1633-1644, 2007.

http://dx.doi.org/10.5194/hess-11-1633-2007

PINTO-DA-ROCHA, R.; ARAÚJO, C.O.; BARREIROS, J.A.P.; BONALDO, A.B. Arthropoda, Arachnida, Scorpiones: Estação Científica Ferreira Penna and Juruti Plateau, Pará, Brazil. Check List, v. 3, n. 2, p. $143-$ 146, 2007. http://www.checklist.org.br/getpdf?NGD017-07

RECKZIEGEL, G. C.; PINTO JUNIOR, V. L. Análise do escorpionismo no período de 2000 a 2010. Rev. Pan-Amaz. Saude, v. 5, n. 1, p. 67-68, 2014. http://dx.doi.org/10.5123/S2176-62232014000100008

SANTOS, M. J. Projeto alternativo de desenvolvimento rural sustentável. Estud. av., v. 15, n. 43, p. 225-238, 2001. http://www.scielo.br/pdf/ea/v15n43/v15n43a17.pdf

SERGIPE. Secretaria de Estado do Planejamento, Orçamento e Gestão. Plano Plurianual 2008-2011. Aracaju (SE). 2007. http://www.seplag.se.gov.br/attachments/article/1347/1.PPA\%202008-

2011\%20\%20Mensagem.pdf

SPIRANDELI CRUZ, E. F. S.; YASSUDA, C. R. W.; BARRAVIERA, J. J. Programa de controle de surto de escorpião Tityus serrulatus, Lutz e Mello 1922, no munícipio de Aparecida, SP (Scorpiones, Buthidae). Rev. Soc. Bras. Med. Trop., v. 28, n. 2, p. 123-128, 1995. http://www.scielo.br/pdf/rsbmt/v28n2/07.pdf

VACHON, M. Études sur les scorpions. Argélia; Institut Pasteur d'Algérie, 1952. 482pp.

WAGATSUMA, L.; MASATO, K.; BARCELLOS, M.; FRUET, D. Influência da mata ciliar e agricultura sobre a temperatura do solo superficial. Instituto Ambiental do Paraná. Cad. biodivers., v. 4, n. 1, p. 26-35, 2003.

http://www.iap.pr.gov.br/arquivos/File/Publicacoes/Cadernos\%20da\%20Biodiversidade/Cadernos\%20da\%20B iodiversidade\%20v\%204\%20n\%201/Capa_Cadernos7.pdf 